\title{
Celiac Disease Revisited
}

\author{
João Calado ${ }^{a}$ Mariana Verdelho Machado ${ }^{a, b}$ \\ ${ }^{a}$ Faculdade de Medicina, Universidade de Lisboa, Lisbon, Portugal; ${ }^{\text {}}$ Hospital de Vila Franca de Xira, Vila Franca de Xira, \\ Portugal
}

\section{Keywords}

Celiac disease · Human leukocyte antigen · Serological tests · Duodenal histology · Diagnostic challenges

\section{Abstract}

Celiac disease (CD) is a systemic disease triggered by gluten ingestion in genetically predisposed individuals. It manifests primarily as an autoimmune enteropathy associated with specific circulating autoantibodies and a human leukocyte antigen haplotype (HLA-DQ2 or HLA-DQ8). It afflicts roughly $1 \%$ of the population, though the majority of patients remain undiagnosed. Diarrhea and malabsorption are classic manifestations of CD; however, both children and adults can be paucisymptomatic and present extraintestinal manifestations such as anemia, osteoporosis, and abnormal liver tests. $C D$ screening is not recommended for the general population, and it should be focused on high-risk groups. CD diagnosis is challenging and relies on serological tests, duodenal histology, and genetic testing. Particularly difficult presentations to manage are seronegative patients, seropositive patients without villus atrophy, and patients who have started a gluten-free diet before the diagnostic workup. The only proven treatment is a lifelong gluten-free diet. We present an in-depth review on the physiopathology and management of CD, with a particular emphasis on diagnostic challenges.
(C) 2021 Sociedade Portuguesa de Gastrenterologia Published by S. Karger AG, Basel

\section{Doença celíaca revisitada}

\section{Palavras Chave}

Doença celíaca · Testes serológicos · Histologia duodenal · Desafios diagnósticos

\section{Resumo}

A doença celíaca (DC) é uma doença sistémica desencadeada pela exposição ao glúten em doentes geneticamente susceptíveis. Manifesta-se maioritariamente por uma enteropatia auto-imune associada a auto-anticorpos e aos haplotipos HLA-DQ2 ou HLA-DQ8. A DC afecta aproximadamente $1 \%$ da população mundial admitindose, no entanto, que a maioria dos doentes não esteja diagnosticada. As manifestações clássicas de DC são a diarreia e sintomas de malabsorção, no entanto tanto crianças como adultos podem ser pauci-sintomáticos ou apresentar manifestações extra-intestinais incluindo anemia, osteoporose ou alteração das provas hepáticas. $\mathrm{O}$ rastreio de base populacional não está recomendado, devendo o foco ser nos grupos de risco para DC. O diagnóstico de DC é um desafio e assenta em três pilares: testes serológicos, histologia duodenal e testes genéticos. Apresentações particularmente difíceis de manejar são os doentes sero-negativos, doentes sero-positivos sem atrofia vilositária e doentes que iniciam dieta sem glúten antes da marcha diagnóstica. O único tratamento com eficá-
Mariana Verdelho Machado

Departmento de Medicina, Gastrenterologia e Hepatologia, Faculdade de Medicina Universidade de Lisboa, Ave. Prof. Egas Moniz

PT-1649-028 Lisboa (Portugal)

mverdelhomachado@gmail.com 
cia comprovada é a dieta sem glúten. Apresentamos uma revisão aprofundada da fisiopatologia e manejo da DC, com particular ênfase nos desafios diagnósticos.

(c) 2020 Sociedade Portuguesa de Gastrenterologia Publicado por S. Karger AG, Basel

\section{Historical Background}

Celiac disease (CD) is a systemic disease triggered by gluten ingestion, in genetically predisposed individuals. It manifests as an autoimmune enteropathy associated with specific circulating autoantibodies and human leukocyte antigen haplotype (HLA-DQ2 or HLA-DQ8) [1].

Aretaeus of Cappadocia, in 250 A.D., described a chronic perturbation of "pepsis" (i.e., digestion) and "anadosis" (i.e., absorption) resulting in a general debility which was named "celiac diathesis" $[2,3]$. The word "celiac" is derived from the Greek "koiliakos," which means abdominal [4]. However, it was only in 1888 that Samuel Gee [5] published the first modern clinical detailed description of CD. In 1908, in the USA, Christian Herter [6] published a similar description, emphasizing the retardation in growth. For several years, CD was known as GeeHerter disease [7].

Diet was proposed as a causal contributor since Arateus. In the twentieth century, several diets were advocated, such as the banana diet [8] and the Fanconi diet based on fruits and vegetables [7]. The causal link to grain consumption (wheat, rye, barley, and, to a lesser extent, oats) was described in the forties by the Dutch pediatrician Willem-Karel Dicke. This link came from the observation of the effect of food scarcity on children with CD during the Second World War. Dicke observed that symptoms of children with CD improved when they were not eating bread or grains and worsened after the war ended and these foods reentered their diet $[7,9]$.

Paulley [10], in 1954, described detailed histological anomalies in the small bowel from surgical specimens (chronic inflammation and atrophy) from patients with CD.

In 1964, Berger et al. [11] reported the presence of serum anti-gliadin antibodies (AGA) in CD. It took up to 20 years for serology be considered a diagnostic criterion $[12,13]$. More sensitive and specific serological tests have been identified since then $[14,15]$.

In 1972, Falchuk et al. [16] described the association between a specific HLA genotype and CD and hypothesized that $\mathrm{CD}$ is a consequence of carrying an abnormal immune response gene to gluten. We know now that
HLA-DQ2/8 is necessary for the development of CD, making HLA determination the third pillar in the diagnosis of CD [17].

\section{Epidemiology}

The prevalence of $\mathrm{CD}$ varies according to age, gender, and region. A recent meta-analysis estimated a global prevalence of $1.4 \%$ by serological tests and $0.7 \%$ by intestinal biopsy [18]. This is probably an underestimation of the real prevalence of $C D$, since it is estimated that only 1 in 5 patients with CD is diagnosed [19]. In some regions, such as Asia and Africa, the number of reported cases of $\mathrm{CD}$ is extremely low, even though wheat consumption is increasing [20] and the frequency of CD-associated HLA alleles seems similar to that in Western countries [21]. As such, in Asia, CD is likely to be even less efficiently diagnosed, with less awareness for the asymptomatic forms of the disease [22]. In this millennium, the prevalence of CD seems to have increased by $33 \%$, for unknown reasons, but it is probably associated with environmental factors [18].

Women are 1.5 times more afflicted than men [18]. The incidence of CD is approximately 2 times more frequent in children than in adults, with a second peak in incidence between 50 and 69 years [23].

Genetics are a main factor in the risk for $C D$, with over 40 genetic loci associations besides the HLA-DQ2/8 haplotype [24].

Environmental factors have been studied as risk factors for CD [25-27]. The association between age at gluten introduction and CD is controversial [28-32]; however, current recommendations advise gluten introduction between 4 and 12 months of age [33]. The amount and pattern of gluten consumption may have a role and may account for the different prevalence rates of $C D$ across Europe [34].

Breastfeeding does not seem to protect from CD [28, $32,35-37]$. Recurrent respiratory infections (in infants) and gastrointestinal infections (rotavirus and adenovirus in children and Campylobacter in adults) seem to be associated with $\mathrm{CD}[25,26,38]$, though the evidence is weak [39].

Lastly, high-risk groups for CD include first-degree relatives of CD patients [40] (with a prevalence up to 7.5\%) [41], and patients with type 1 diabetes mellitus (T1DM) [42] or other autoimmune diseases [43], IgA deficiency [44], and chromosomopathies such as Down syndrome [45] and Turner syndrome [46]. 
Table 1. HLA and the risk of CD

\begin{tabular}{|c|c|c|c|c|c|c|c|}
\hline \multirow[t]{2}{*}{ Haplotype } & \multicolumn{3}{|c|}{ HLA alleles } & \multicolumn{3}{|c|}{ Molecules } & \multirow[t]{2}{*}{ Risk of CD } \\
\hline & DQB1* & DQA1* & DRB1* & $\beta$ chain & a chain & & \\
\hline DR3-DQ2 & 02:01 & 05:01 & 03 & 02:01 & 05:01 & cis DQ2.5 & high \\
\hline $\begin{array}{l}\text { DR5-DQ7 } \\
\text { DR7-DQ2 }\end{array}$ & $\begin{array}{l}03: 01 \\
02: 02\end{array}$ & $\begin{array}{l}\text { 05:05 } \\
02: 01\end{array}$ & $\begin{array}{l}11 / 12 \\
07\end{array}$ & 02:02 & 05:05 & trans DQ2.5 & \\
\hline DR7-DQ2 & 02:02 & 02:01 & 07 & 02:02 & 02:01 & DQ2.2 & low \\
\hline DR5-DQ7 & 03:01 & 05:05 & $11 / 12$ & 03:01 & 05:05 & DQ7.5 & very low \\
\hline DR4-DQ8 & 03:02 & 03 & 04 & 03:02 & 03 & DQ8 & low \\
\hline
\end{tabular}

Adapted from Sollid [57].

\section{Pathophysiology}

CD results from an intense immune response to gluten leading to small bowel injury with consequent malabsorption and autoimmune phenomena [47].

Gluten consists of a group of proteins from Gramineae of the Triticiae tribe, particularly wheat, rye, and barley. Oats are phylogenetically more distant (Aveneae tribe) but share sufficient similarities to induce symptoms in some patients. Rice, maize, sorghum, and millet are distant enough not to trigger CD [48]. Gluten is the Latin word for "glue," owing its name to its viscoelastic and adhesive properties [26]. The word gluten is widely used to refer to disease-inducing Gramineae proteins; however, strictly speaking, gluten specifically refers to proteins from wheat. Similar proteins in rye are secalins, and in barley they are hordein [49]. Wheat gluten contains 2 major protein components, i.e., monomeric water-soluble gliadins and multimeric water-insoluble glutenins [50].

Gluten peptides are highly enriched in proline and glutamine. Gastrointestinal proteases are deficient in prolylendopeptidase activity. As such, the high-proline content makes gluten resistant to gastrointestinal cleavage, allowing the subsistence of polypeptides with up to 33 amino acids [51]. This increases gluten's immunogenicity, since major histocompatibility complex (MHC) II molecules only present peptides at least 9 amino acids long [52].

Gluten peptides are not freely absorbed and need a disruption in the epithelial barrier to translocate into the lamina propria, where antigen-presenting cells (APC) reside. That may occur through a damaged epithelium, induced by transient intestinal infection, drug-induced inflammation (e.g., nonsteroidal anti-inflammatory drugs), or dysbiota-induced disassembly of enterocyte tight junctions. Alternatively, gluten can cross the epithelium in a transcellular pathway through binding of gluten-secreto- ry IgA complexes to the transferrin receptor CD71 or inside dendritic cells that cross the epithelium $[17,50,53-$ 55].

MHC-II molecules bind preferentially to peptides with negatively charged amino acids. Even though gluten peptides have very few charged amino acids, they are highly susceptible to deamidation on their glutamine residues to negatively charged glutamate by tissue transglutaminase (tTG) [52]. Deamidation significantly increases the stability of the gluten-MHC complex, increasing their immunogenicity [56].

APC present deamidated gluten peptides bound to a specific MHC class II that map to the HLA-DQ locus. That locus codifies antigen-presenting glycoproteins that are heterodimers constituted by a $\alpha$-chain (encoded by the DQA1 allele) and a $\beta$-chain (encoded by the DQB1 allele). Only HLA-DQ2.5, DQ2.2, and DQ8 (and probably DQ7.5) bind to deamidated gluten peptides, and so their presence is necessary for the development of CD. However, it is not a sufficient condition, since these haplotypes are also found in $40 \%$ of the general population $[53,57]$. Nonetheless, about $90 \%$ of CD patients express HLA-DQ2.5 and roughly $10 \%$ express HLA-DQ2.2 or HLA-DQ8 [58]. HLA-DQB1*02, present in HLA-DQ2.5 and HLA-DQ2.2, confers a higher risk for CD compared to the presence of HLA-DQB ${ }^{*} 03$, present in HLA-DQ8. The frequency of HLA-DQB1*02 seems to be even higher in CD patients with T1DM [59]. Furthermore, there is a dose effect for HLA-DQ2.5, since homozygous individuals have a 5 -fold increased risk for $\mathrm{CD}$ and for severe disease [60]. Haplotypes, HLA, and their risk are shown in Table 1.

APC (dendritic cells and macrophages) present the complex MHC-II-deamidated gliadin to CD4+ T cells, inducing a proinflammatory phenotype in T cells [61]. Activated $\mathrm{CD} 4+\mathrm{T}$ cells promote differentiation of $\mathrm{B}$ cells into 


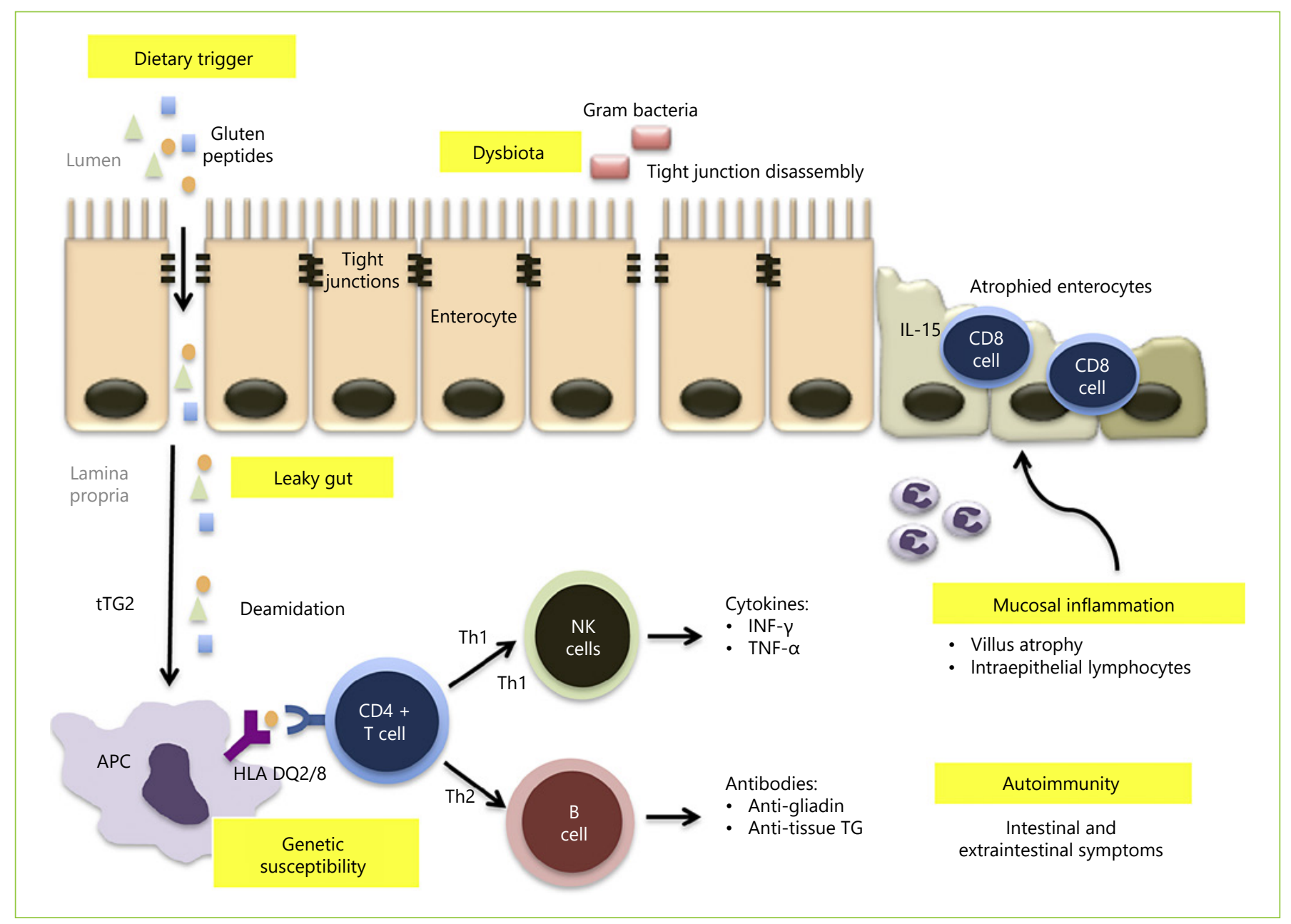

Fig. 1. Pathogenesis of $C D$. Gluten peptides reach the lamina propria through a leaky gut, with increased intestinal permeability, which may be due to drug-induced inflammation or dysbiota-induced disassembly of enterocyte tight junctions. Gluten peptides are then deamidated by tTG, which allows them to be presented to CD4-T cells by APC that exhibit MHC class II molecules encoded by the haplotypes HLA-DQ2 or HLA-DQ8. This will trigger T-helper 1 and T-helper 2 immune responses that result in mucosal cytotoxicity and inflammation, as well as autoimmune extraintestinal phenomena.

plasma cells and release proinflammatory cytokines such as interferon- $\gamma$ and interleukin-21 that activate intraepithelial CD8+ T cells $[17,58]$. Interleukin-15 further promotes intraepithelial CD8+ T cell differentiation into a cytotoxic NK cell-like phenotype, damaging enterocytes [61]. Activated CD4+ T cells also secrete tumor necrosis factor- $\alpha$, which acts on intestinal fibroblasts inducing their secretion of: (1) matrix metalloproteinases (contributing to mucosal destruction by dissolution of connective tissue) [62] and (2) epithelial mitogen keratinocyte growth factor (contributing to crypt epithelial cells hyperplasia) [63].

Lastly, tTG-deamidated gluten complex may bind to receptors allowing internalization into specific B cells, which then act as APC to CD4+ T cells, further fueling the immune response. Conversely, those B cells may differentiate into plasma cells, explaining why specific antitTG antibody production only occurs under a glutencontaining diet [64]. The pathophysiology of CD is summarized in Figure 1.

\section{Clinical Manifestations and Associated Diseases}

The clinical spectrum of CD is broad, which accounts for the challenging diagnosis. Classical gastrointestinal manifestations are more common in children, whereas 
adults tend to be paucisymptomatic [25]. Classical manifestations are chronic diarrhea (in 35\%), abdominal pain $(28 \%)$, and weight loss $(22 \%)[53,65]$. CD can also present paradoxically with chronic constipation (20\%), abdominal distension (20\%), gastroesophageal reflux (12\%), and even obesity $[25,53]$.

The most common extraintestinal manifestations are decreased bone mineralization (osteopenia in 50-70\% and osteoporosis in 5.5\% of cases), anemia (32\%), arthralgia $(29 \%)$, fatigue $(26 \%)$, and neurological symptoms (20\%), particularly gluten ataxia and peripheral neuropathy $[53,66]$. Gluten ataxia is an autoimmune injury of the cerebellum, induced by gluten ingestion, which manifests with a typical serology and abnormal gait, muscle coordination, and fine control of voluntary movements, as well as cerebellum atrophy on magnetic resonance imaging (up to 60\%). The mean age at onset is around 50 years [67] and the effect of a gluten-free diet (GFD) is controversial [68-71]. Gluten neuropathy is a sensitive neuropathy that is associated with serological evidence of $C D$, which initially affects the hands and feet but usually progresses. The mean age at diagnosis is 55 years and a GFD can improve symptoms regardless of the presence or absence of enteropathy [71].

CD can also manifest with hypertransaminasemia (9$14 \%)$, recurrent aphthous stomatitis, tooth enamel defects, infertility, delayed puberty, and a short stature [53, $66,72]$. Most extraintestinal manifestations improve with a GFD, but an early diagnosis is crucial and some manifestations, such as enamel defects, may be irreversible [66].

$\mathrm{CD}$ is associated with many genetic disorders. The prevalence of $\mathrm{CD}$ is higher in patients with chromosomopathies (i.e., 5-10\% in patients with Down, Turner, and Williams syndromes) [73]. This might be explained by the proinflammatory millieu and impaired function of CD4+ $\mathrm{T}$ cells associated with chromosomopathies [46, 74].

Autoimmune glandular diseases, particularly T1DM and thyroid disease, are strongly associated with CD; 10 $30 \%$ of CD patients have 1 of those 2 autoimmune diseases and up to $7 \%$ of patients with autoimmune glandular diseases have $C D[25,75]$. In fact, those conditions share a genetic background with a tight link to HLADQ2/8 and DR3/4 [75]. Interestingly, the prevalence of autoimmune diseases increases with increasing age at diagnosis, probably as a consequence of a higher duration of exposure to gluten [76].

Herpetiform dermatitis (HD) is a dermatological autoimmune disease that also shares a genetic background
Table 2. Current recommendations on CD screening

\begin{tabular}{|c|c|}
\hline Offer serological testing & Consider serological testing \\
\hline $\begin{array}{l}\text { - Persistent unexplained abdominal } \\
\text { or gastrointestinal symptoms } \\
\text { - Faltering growth } \\
\text { - Prolonged fatigue } \\
\text { - Unexpected weight loss } \\
\text { - Severe or persistent mouth ulcers } \\
\text { - Unexplained iron, vitamin } \mathrm{B}_{12} \text {, or } \\
\text { folate deficiency } \\
\text { - T1DM } \\
\text { - Autoimmune thyroid disease } \\
\text { - Irritable bowel syndrome } \\
\text { - First-degree relatives of CD pa- } \\
\text { tients }\end{array}$ & $\begin{array}{l}\text { - Unexplained persistent } \\
\text { raised liver enzymes } \\
\text { - Metabolic bone disorder } \\
\text { - Unexplained subfertility } \\
\text { or recurrent miscarriage } \\
\text { - Dental enamel defects } \\
\text { - Unexplained neurologic } \\
\text { symptoms } \\
\text { - Down syndrome } \\
\text { - Turner syndrome }\end{array}$ \\
\hline
\end{tabular}

Adapted from Downey et al. [86].

with CD. Up to $20 \%$ of CD patients develop HD and more than $90 \%$ of HD patients have CD. HD diagnosis can be confirmed by skin biopsy demonstrating IgA deposits in the papillary dermis adjacent to the lesion. These patients present anti-tTG as well as IgA anti-epidermal transglutaminase antibodies. HD responds to GFD, although transient treatment with dapsone may be needed $[25,66$, 77].

CD patients have an increased risk of hepatic diseases such as steatosis, autoimmune hepatitis, primary biliary cholangitis (at least a 20-fold increase) [78], and primary sclerosing cholangitis (4- to 8-fold increase) [79].

Finally, patients with a selective IgA deficiency present a risk of $C D$ that is 10-20 times higher [80]. The reverse is also true, i.e., IgA deficiency is $10-15$ times more frequent in patients with $\mathrm{CD}$ [81].

\section{Diagnosis}

\section{Who to Test?}

Current guidelines recommend testing for CD patients with signs, symptoms, or laboratorial evidence of malabsorption, unexplained fatigue, and recurrent mouth ulcers. Furthermore, patients with T1DM or autoimmune thyroid disease should be regularly tested $[82,83]$. Importantly, the presence of symptoms is not required for a diagnosis of CD [84].

$\mathrm{CD}$ screening is recommended in patients with irritable bowel syndrome, since these patients are 4 times more likely to have $\mathrm{CD}$ than the general population, even pa- 
Fig. 2. CD diagnosis flowchart.

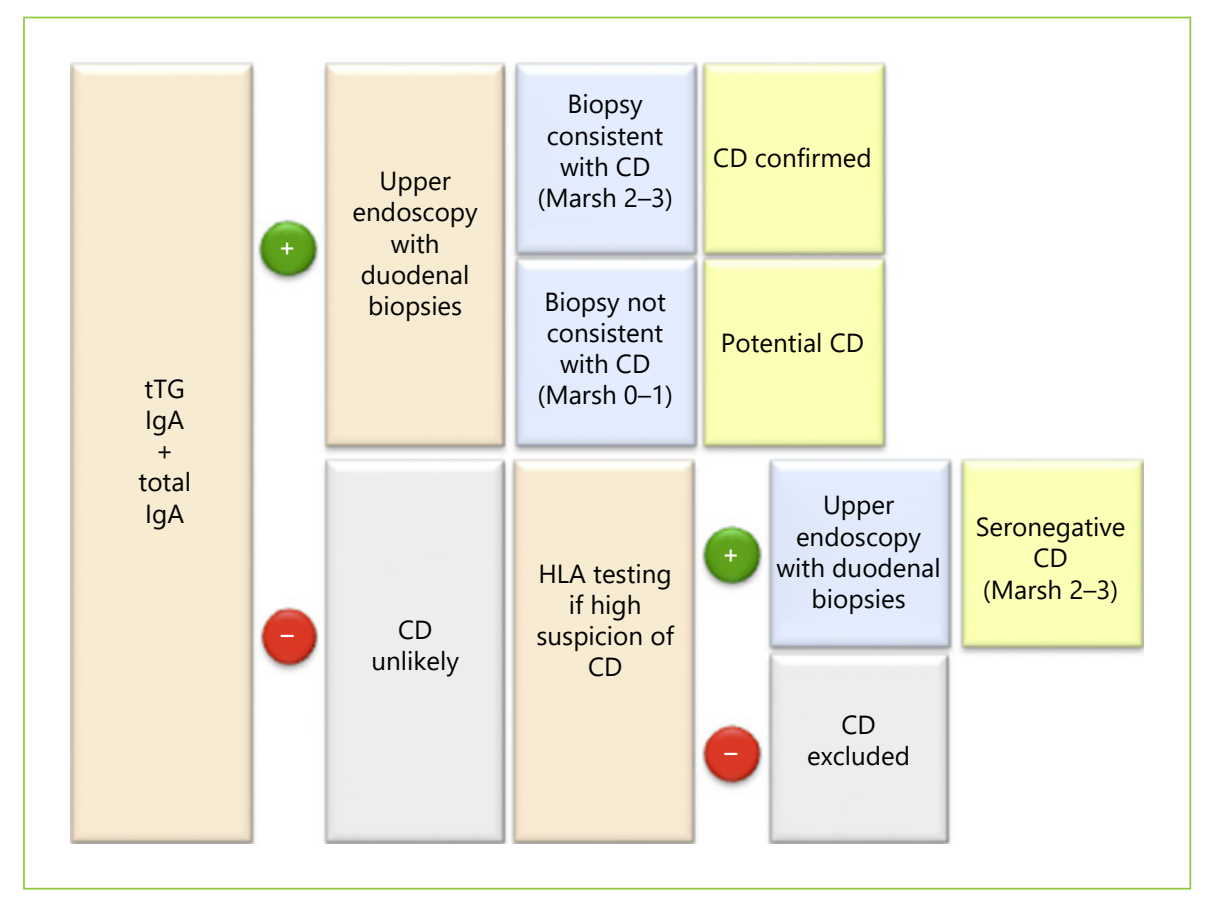

tients presenting with obstipation [85]. Lastly, first-degree relatives of $\mathrm{CD}$ patients should be screened, though there are no recommendations regarding the time interval for rescreening [73].

The following high-risk groups should also be considered for screening: children and adolescents with chromosomopathies and patients with metabolic bone disorders, unexplained neurological symptoms, hypertransaminasemia or infertility, and dental enamel defects [73]. CD screening recommendations are displayed in Table 2.

Population-based screening is not recommended, since it has not been proven that the diagnosis of asymptomatic patients improves their quality of life $[87,88]$.

\section{Diagnostic Tools}

CD diagnosis relies on 3 main pillars, i.e., serological tests, duodenal histology, and genetic testing [89]. The diagnostic algorithm is presented in Figure 2.

Anti-tTG IgA is the recommended first-line serological test, as it is the most sensitive test (98\%) and has a very good specificity (96\%) [47]. Anti-tTG is determined through ELISA, allowing quantitation. Anti-endomysial (EMA) IgA reacts to the same antigen of $\mathrm{tTG}$, but bound to tissue, requiring immunofluorescence in tissue from primate oesophagus or human umbilical cord. As such, EMA is more expensive, technically more challenging, and operator dependent, and it only allows qualitative results [90]. The anti-EMA IgA test is the most specific se- rological test [91] and it should be used as a confirmatory test, especially when the anti-tTG level is lower than 2 times the upper limit of normal $[83,89]$. Anti-tTG and anti-EMA IgG have a low sensitivity and should be interpreted carefully [91].

AGA is not recommended for $\mathrm{CD}$ diagnosis due to the low sensitivity and specificity $[82,92]$. More recently, anti-deamidated gliadin peptides (DGP), which are assessed by an ELISA assay, have been adopted, particularly IgG that is superior to other IgG antibodies (88\% sensitivity and $99 \%$ specificity) [91]. Anti-DGP IgG is particularly useful in patients with a selective IgA deficiency $[83,93]$.

Diagnosis should start with measurement of both antitTG IgA and IgA serum levels. Positive anti-tTG IgA should prompt duodenal biopsies to confirm the diagnosis. When the anti-tTG IgA titer is low $(4-10 \mathrm{U} / \mathrm{mL})$ with normal IgA levels, anti-EMA IgA should be assessed. Lastly, when IgA $<1 \mathrm{mg} / \mathrm{dL}$, IgG antibodies should be assessed (particularly anti-DGP IgG) [90].

All serological tests should be performed under a gluten-containing diet to avoid false-negative results [82]. False-positive results may occur with intestinal infections (e.g., Giardia lamblia) [94], chronic liver disease [95], congestive heart failure [96], and hypergammaglobulinemia [97]. Of note, serological tests have demonstrated high intertest and interlaboratory variability at lower ranges, and this should be confirmed by alternative tests when levels are lower than 10 times the upper limit of normal [84]. 
All patients with positive serological tests should undergo an upper endoscopy with duodenal biopsies [73]. Endoscopy is also indicated in patients with negative serological tests when the clinical suspicion is high [82].

Endoscopic findings alone present a sensitivity that ranges from 11 to $22 \%$ for CD [98]. Some findings, however, are very specific (up to 99\%) for mucosal atrophy, i.e., scalloping duodenal folds, fissuring, and a mosaic pattern of the mucosa $[99,100]$. Less specific findings are duodenal erosions, loss of folds, nodular mucosa, and enhanced submucosal vessels $[99,101]$. The role of advanced endoscopic techniques such as immersion endoscopy [102], NBI [103], iSCAN [104], and confocal endomicroscopy [105] is still unclear [106]. Capsule endoscopy may be useful for patients who refuse endoscopy and in complicated CD [107].

Histology is crucial for the diagnosis of CD in adults, and the way endoscopic biopsies are collected determines their accuracy. At least 4 duodenal biopsies should be collected, since the distribution of lesions is discontinuous [82]. Furthermore, 1 or 2 biopsies should be collected from the duodenal bulb (from the 9 or 12 o'clock position), since it increases (by almost 10\%) the sensitivity in adults [108]. Bulb biopsies should be interpreted carefully and sent separately from more distal duodenal samples. Indeed, less than half of all bulb biopsies are high quality; their quality is hampered by the presence of Brunner glands and lymphoid tissue, peptic duodenitis, and gastric metaplasia. Furthermore, villi are smaller in the bulb and can be misinterpreted as atrophic $[109,110]$. Finally, biopsies should be collected one-bite (rather than doublebite) at each pass of the forceps, since this decreases the risk of losing specimens, increases (3-fold) the chance of good orientation, and minimizes the risk of tangential biopsies that overestimate mucosal atrophy $[111,112]$. Duodenal biopsies should be performed under a gluten-containing diet to avoid false negatives [90].

Histopathological findings characteristic of $\mathrm{CD}$ are intraepithelial lymphocytosis ( $\geq 25$ IEL/ 100 enterocytes when sections are 3-4 um), crypt hyperplasia, and villous atrophy $[90,113]$. A normal histology presents a gradient of IEL (more numerous at the base of the villi and decreasing toward the tip), and the villous:crypt ratio is 3-5:1 [114]. Histological abnormalities are classified according to the Marsh scale, modified by Oberhuber [113] as shown in Table 3.

Children tend to present, more frequently, mucosal atrophy (Marsh 3 lesions) on duodenal biopsies, whereas it is common to diagnose adults without villous atrophy and an inflammatory pattern with IEL (Marsh 1 or 2) [115].

CD Revisited
Table 3. Modified Marsh classification

\begin{tabular}{lllll}
\hline $\begin{array}{llll}\text { Marsh } \\
\text { type }\end{array}$ & \multicolumn{4}{l}{ Histological criterion $($ Marsh modified by Oberhuber) } \\
\cline { 2 - 5 } & $\begin{array}{l}\text { IEL }>25 / 100 \\
\text { enterocytes }\end{array}$ & $\begin{array}{l}\text { crypt } \\
\text { hyperplasia }\end{array}$ & $\begin{array}{l}\text { villous } \\
\text { atrophy }\end{array}$ & $\begin{array}{l}\text { villous: } \\
\text { crypt ratio }\end{array}$ \\
\hline 0 & $\times$ & $\times$ & $\times$ & $3-5: 1$ \\
1 & $\sqrt{ }$ & $\times$ & $\times$ & \\
2 & $\sqrt{ }$ & $\sqrt{ }$ & $\times$ & \\
$3 \mathrm{a}$ & $\sqrt{ }$ & $\sqrt{ }$ & partial & $<3: 1$ \\
$3 \mathrm{~b}$ & $\sqrt{ }$ & $\sqrt{ }$ & subtotal \\
$3 \mathrm{c}$ & $\sqrt{ }$ & $\sqrt{ }$ & total & 0 \\
\hline
\end{tabular}

A positive serology associated with a compatible histology (Marsh 2-3) confirms the CD diagnosis $[73,116]$.

Even though genetic testing is not required for the diagnosis of $\mathrm{CD}$, it may be important to exclude $\mathrm{CD}$, since the absence of HLA-DQ2/8 has a negative predictive value of virtually $100 \%$ [117]. This is particularly useful in seronegative patients, patients on a GFD who are unable/ unwilling to undergo a gluten challenge, or those who refuse endoscopy [73, 92, 93, 118].

Research on CD is moving toward an endoscopyfree diagnosis of CD. Keeping that in mind, a study found a positive predictive value of $100 \%$ with the triple combination of a positive genetic test, positive antiEMA, and over 10-fold increased anti-tTG titers [119]. In fact, recent European guidelines state that, in children, a duodenal biopsy may not be required if anti-tTG $\operatorname{IgA}$ is more than 10 times the upper limit of normal and anti-EMA IgA is positive in a second blood sample. In such cases, a serology-based diagnosis can be established even in the absence of symptoms and without genetic testing. On the other hand, when anti-tTG IgA titles are positive but low, duodenal biopsy should always be performed [84].

Furthermore, several noninvasive markers, such as intestinal fatty acid binding protein (I-FABP), a marker of enterocyte injury, are currently being evaluated. Patients with CD present higher serum levels compared to controls, which correlate with mucosal atrophy. I-FABP levels normalize after a GFD in $80 \%$ of children but not in adults [120]. Some studies also suggest a role of I-FABP in assessing adherence to a GFD and accidental gluten ingestion [121].

Another promising technique is flow cytometry that recognizes blood CD4+ T cells that bind to HLA-DQgluten tetramers. Preliminar studies have shown a very good accuracy in differenciating CD patients from controls, even on a GFD $[122,123]$. 


\section{Diagnostic Challenges}

Seronegative-CD refers to a compatible histology and HLA, with a negative serology, and corresponds to $2 \%$ of CD patients $[124,125]$. To confirm seronegative $C D$, the histology must improve after GFD. However, GFD is advised only after excluding other diagnoses, since seronegative $\mathrm{CD}$ accounts for $<30 \%$ of seronegative villous atrophy or epithelial lymphocytosis $[90,126,127]$. As such, these should be excluded: autoimmune enteropathy (anti-enterocyte antibody positive), common variable immunodeficiency, Crohn disease, eosinophilic gastroenteritis, infectious diseases (Whipple disease, G. lamblia, tuberculosis, HIV-associated enteropathy, and tropical sprue), bacterial overgrowth, lymphoproliferative diseases, and drug-associated enteropathy. The drugs most frequently implicated are nonsteroidal anti-inflammatory drugs, immunosuppressors (azathioprine, mycophenolate mofetil, and methotrexate), and angiotensin receptor antagonists, in particular olmesartan, which is responsible for one fifth of seronegative duodenal-atrophy cases in the USA [116, 128-130]. In CD, IEL is composed solely of CD8+ T cells, whereas in non-CD villous atrophy IEL has mixed CD8+ and CD4+ T cells. CD-associated lymphocytosis is also suggested when over $5 \%$ of T-cell receptors in IEL are $\gamma / \delta$ and when the base-tip decrescendo gradient is lost $[90,114,131]$. Importantly, non-CD mucosal atrophy reverts spontaneously, without GFD, in over two thirds of patients [126].

Compared to seropositive patients, seronegative CD patients tend to be older (age 49 vs. 36 year) but they present more frequently the classic phenotype [125]. The physiopathology of seronegative CD is not yet clear, but some studies have suggested a high antibody-antigen binding affinity entrapping antibodies in the lamina propria away from the bloodstream. Accordingly, detection of tTG-anti-tTG immunocomplexes in the mucosa can help to identify these patients [132]. Other explanations for seronegative $\mathrm{CD}$ are immune system immaturity [133], selective IgA deficiency, a diet poor in gluten, treatment with immunossupressors, and refractory long-term CD [126].

Potential CD (PCD) refers to seropositive patients with a normal duodenal mucosa (Marsh 0) or intraepithelial lymphocytosis (Marsh 1) without crypt hyperplasia or villous atrophy. PCD accounts for $10 \%$ of CD patients [93]. Whereas over $80 \%$ of children are asymptomatic $[134,135]$, the majority of adults $(79 \%)$ with PCD are symptomatic, mostly with a nonclassic phenotype [136]. Symptomatic PCD patients should be kept on a GFD, since it results in clinical improvement. The management of asymptomatic PCD patients is less straightforward, since the progression rate to overt CD is low, i.e., $13 \%$ in 10 years [137]. Asymptomatic PCD patients may maintain a gluten-containing diet, with evaluation every 6 months for symptoms and serology and a duodenal biopsy every 2 years if there is a persistently positive serology [136].

Patients on a GFD prior to CD diagnosis may be tested for HLA since the absence of HLA-DQ2/8 excludes CD. In the presence of HLA-DQ2/8, patients should repeat the diagnostic workup after a gluten challenge [138]. Traditionally, a gluten challenge consists of consumption of 7.5 $\mathrm{g} /$ day of gluten for 6-8 weeks; however, $3 \mathrm{~g}$ /day of gluten (equivalent to 2 slices of bread) is as effective. For patients who cannot tolerate a long gluten challenge, recent studies suggest that 2 weeks may be enough. One caveat is that, whereas histology can be performed immediately after the challenge, serology must be postponed 2 more weeks after the 2-week challenge. This approach allows a correct diagnosis in more than $75 \%$ of CD patients [138].

Non-celiac gluten sensitivity (NCGS) is a functional disorder that must be differentiated from CD. NCGS is 6 times more prevalent than CD [139], and it is more frequent in females in their second or third decade [140]. Clinical manifestations are elicited by gluten ingestion and they are similar to CD [141]; however, the kinetics between gluten ingestion and symptoms is much faster; intestinal or extra-intestinal symptoms develop and resolve hours to days after gluten ingestion or eviction [142, 143]. Furthermore, NCGS is not associated with autoimmune disorders. NCGS diagnosis is clinical with demonstration of symptoms resolution with a GFD, and recurrence after rechallenge, and requiring exclusion of $\mathrm{CD}$ and wheat allergy $[141,144]$. The pathogenesis is unknown, though it is probably multifactorial, resulting from an interplay between the environment (other components of wheat), intestinal barrier dysfunction, gut dysbiota, and diregulated innate imune responses [140].

\section{Management}

A lifelong GFD is the only proven treatment and is recommended for classical, nonclassical, seronegative CD, symptomatic PCD, and HD or gluten ataxia [93]. GFD is not recommended for asymptomatic adults with PCD, since only a minority of these patients will develop villus atrophy [136].

A GFD consists of a strict elimination of wheat (and its gluten-containing derivatives bulgur, couscous, and seit- 
an) [89], rye, and barley [145]. Elimination of oats is not so straightforward. In fact, oats contain avenin, a peptid related to gluten that may elicit similar immune reactions. Oats can also induce symptoms by an increase in fiber content. Hence, the oat intake should not exceed 50-60 g/ day and patients should be clinically and serologically monitored. Oats should be avoided in severe disease [146].

The tolerable amount of gluten is variable, but as little as $1 / 100^{\text {th }}$ of a slice of bread (around $50 \mathrm{mg}$ of gluten) is sufficient to induce mucosal atrophy. Gluten-free is defined as $<20 \mathrm{ppm}$ of gluten (around $6 \mathrm{mg} /$ day) $[147,148]$. Patients should be aware of nondietary potential sources of gluten contamination such as tooth paste and lipstick.

Gastrointestinal symptoms improve after 1 month and usually disappear after 6 months on a GFD [149]. Most patients become seronegative after 6 months on a GFD and only $17 \%$ remain seropositive after 1 year $[150,151]$, suggesting gluten contamination [73]. Anti-tTG IgA is the preferred serological test to monitor GFD adherence. Histological normalization takes longer, particularly in adults, in whom it takes $2-5$ years [152]. Only $66 \%$ of patients on a GFD achieve a total histological recovery after 1 year, in contrast with the expected recovery in $95 \%$ of children [153].

A GFD can also improve extraintestinal manifestations and CD-related conditions. However, some manifestations such as enamel defects and osteopenia may be irreversible or just partially corrected $[66,154]$.

The GFD should be lifelong, even if the patient acquires a clinical tolerance to gluten. Although $20 \%$ of patients maintain histological remission after gluten reintroduction, IEL and a positive serology tend to remain, and those patients are at an increased risk for extraintestinal manifestations and late relapse [155]. Importantly, strict adherence to a GFD is low, i.e., $17-48 \%[156,157]$, and mortality seems to increase 5 -fold in patients who do not comply with a GFD [158].

Alternative therapies are under investigation but none has shown sufficient efficacy yet to enter clinical practice. Investigational drugs include genetically modified less immunogenic wheat strains, prolyl endopeptidases, nonabsorbable polymers with a high affinity for gliadin, drugs that act on intestinal permeability gluten deamination, and HLA inhibitors, among others [159].

Patients should be monitored at 6 months and then yearly for GFD adherence, symptoms, serology, a micronutrient deficiency, and associated conditions. Laboratorial tests should include anti-tTG IgA, a full blood count, iron, folic acid, vitamin $B_{12}$, calcium, vitamin $\mathrm{D}$, thyroid function, and anti-thyroid antibodies [26, 152]. Follow- up endoscopy is advised for persistent or relapsing symptoms despite a GFD [82]. Osteodensitometry should be assessed every 1-2 years [89]. Lastly, vaccination against pneumococci, Haemophilus influenza, and meningococci are strongly recommended [73].

About $1.5 \%$ of $C D$ patients progress to refractory $C D$ (RCD), defined as persistence of clinical malabsorption and villous atrophy, after 1 year on GFD, after exclusion of other causes for villous atrophy or malignancy [116]. The main cause of persistent villous atrophy is inadvertent gluten ingestion. Other conditions, i.e., lactose intolerance, irritable bowel syndrome, small bowel bacterial overgrowth, pancreatic insufficiency, and microscopic colitis, should be excluded [83].

RCD is subclassified into types I and II, according to phenotype and clonality of IEL. In type I RCD, IEL are phenotypically normal with polyclonality of the T-cell receptor, whereas in typeII T cells are aberrant, lacking surface CD8 and CD3 expression while expressing intracytoplasmatic $\mathrm{CD} 3$, and presenting a monoclonal receptor rearrangement. The distinction of these 2 entities is crucial because the treatment and prognosis are different $[89$, $160,161]$. Type I RCD usually responds to steroids and budesonide or immunomodulators such as azathioprine. Type II RCD is more aggressive and it is associated with ulcerative jejunoileitis, severe malabsorption, a high risk of progression to enteropathy-associated T-cell lymphoma (EATL) (50\%, in 5-10 years) [154, 162], and a 5-year survival rate of $44-58 \%[154,160]$. Type II RCD does not respond to steroids, should not be treated with azathioprine because of concerns of an increase in the risk for EATL, and may require treatment with cladribine or an autologous/allogenic bone marrow transplant. Targeting of IL-15 is a promising therapeutic strategy [163].

Patients with CD, especially long-standing and untreated patients, present a higher risk for EATL and small intestine adenocarcinoma compared to the general population. The 5 -year survival rate for EATL is $11 \%$. The risk of developing other malignancies is still an unanswered topic $[89,164-166]$.

CD patients seem to have a $20 \%$ increase in mortality, particularly in those diagnosed as young adults and in the first 2 years after the diagnosis. Of note, increased mortality in $\mathrm{CD}$ patients seems to occur even 10 years after the diagnosis [167]. The mortality rate is probably influenced not only by the age at diagnosis but also by the severity of the presentation, the adherence to a GFD, the ammount of gluten intake, and associated conditions [168].

Specific mortality increases in lymphoproliferative disorders, with a 2 -fold increase particularly in women 
over 50 years of age and in the 2 years following the diagnosis. In fact, in a Finnish study on 12,803 CD patients followed for 7 years, $55 \%$ of CD patients died from T-cell lymphoma, compared to $3 \%$ of the reference population [169]. Globally, however, no increased risk for cancerrelated mortality has been proven [166]. Importantly, CD patients seem to have a 5-fold increased risk of dying from infections, particularly sepsis [169].

\section{Conclusions}

$\mathrm{CD}$ is still an underdiagnosed entity that poses a diagnostic challenge despite having been described, for the first time, almost 2 thousand years ago. It presents a wide range of unspecific signs and symptoms, both gastrointestinal and extraintestinal. Adults tend to be paucisymptomatic, presenting nonclassical symptoms which can also occur in children. As such, even though populationbased screening is not recommended, physicians should use an active case-finding strategy with a low threshold for screening.

Diagnosis requires highly accurate serological tests and a compatible duodenal histopathology, although in children duodenal biopsy may be avoided if the anti-tTG is higher than 10 times the upper limit of normal and anti-EMA is positive in a second blood sample. The presence of HLA-DQ2/8 is mandatory for the development of
$\mathrm{CD}$, being particularly helpful in excluding CD. Typical histology findings such as villous atrophy and crypt hyperplasia are unspecific and other diseases, such as Crohn disease, infections, and drug-induced duodenitis, must be excluded.

A lifelong GFD is the only treatment with proven efficacy; however, adherence to this diet is very low. As such, a GFD must be emphasized and monitored regularly. CD patients seem to have an increased mortality, most likely if left untreated.

Current and future research on CD should address endoscopy-free diagnostic algorithms, easier monitoring of dietary gluten contamination, and alternative nondietary therapeutic strategies.

\section{Conflict of Interest Statement}

The authors have no conflict of interests to declare.

\section{Funding Sources}

The authors received no financial support for the research, authorship, or publication of this article.

\section{Author Contributions}

J.C. wrote this review. M.V.M. wrote and corrected this review.

\section{References}

1 Ludvigsson JF, Leffler DA, Bai JC, Biagi F, Fasano A, Green PH, et al. The Oslo definitions for coeliac disease and related terms. Gut. 2013 Jan;62(1):43-52.

2 Dowd B, Walker-Smith J. Letter: samuel Gee, Aretaeus, and the coeliac affection. Br Med J. 1974 May;2(5916):442.

3 Gasbarrini GB, Mangiola F, Gerardi V, Ianiro G, Corazza GR, Gasbarrini A. Coeliac disease: an old or a new disease? History of a pathology. Intern Emerg Med. 2014 Apr;9(3):249-56.

4 Freeman HJ. Celiac disease: a disorder emerging from antiquity, its evolving classification and risk, and potential new treatment paradigms. Gut Liver. 2015 Jan;9(1):28-37.

5 Gee S. On the coeilac affection. St Bartholemews Hosp Rep. 1888;24:17.

6 Herter CA. On infantilism from chronic intestinal infection, characterized by the overgrowth and persistence of flora of the nursling period. New York: MacMillan; 1909. p. 416.

7 Yan D, Holt PR. Willem Dicke. Brilliant clinical observer and translational investigator. Discoverer of the toxic cause of celiac disease. Clin Transl Sci. 2009 Dec;2(6):446-8.
8 Haas SV. The value of the banana in the treatment of coeliac disease. Am J Dis Child. 1924; 24:421-37.

9 van Berge-Henegouwen GP, Mulder CJ. Pioneer in the gluten free diet: Willem-Karel Dicke 1905-1962, over 50 years of gluten free diet. Gut. 1993 Nov;34(11):1473-5.

10 Paulley JW. Observation on the aetiology of idiopathic steatorrhoea; jejunal and lymphnode biopsies. BMJ. 1954 Dec;2(4900):131821.

11 Berger E, Burgin-Wolff A, Freudenberg E. Diagnostisehe Bewertung des Nachweises yon Gliadin-AntikSrpern bei Cöliakie. Klinische Wochenschrift. 1964;42:788-90.

12 Kilander AF, Dotevall G, Fällström SP, Gillberg RE, Nilsson LÅ, Tarkowski A. Evaluation of gliadin antibodies for detection of coeliac disease. Scand J Gastroenterol. 1983 May;18(3):377-83.

13 Signer E, Bürgin-Wolff A, Berger R, Birbaumer A, Just M. Antibodies to gliadin as a screening test for coeliac disease. A prospective study. Helv Paediatr Acta. 1979 Feb; 34(1):41-52.
14 Dieterich W, Ehnis T, Bauer M, Donner P, Volta U, Riecken EO, et al. Identification of tissue transglutaminase as the autoantigen of celiac disease. Nat Med. 1997 Jul;3(7):797801.

15 Chorzelski TP, Beutner EH, Sulej J, Tchorzewska H, Jablonska S, Kumar V, et al. IgA antiendomysium antibody. A new immunological marker of dermatitis herpetiformis and coeliac disease. Br J Dermatol. 1984 Oct; 111(4):395-402.

16 Falchuk ZM, Rogentine GN, Strober W. Predominance of histocompatibility antigen HLA8 in patients with gluten-sensitive enteropathy. J Clin Invest. 1972 Jun;51(6):1602-5.

17 Parzanese I, Qehajaj D, Patrinicola F, Aralica M, Chiriva-Internati M, Stifter S, et al. Celiac disease: from pathophysiology to treatment. World J Gastrointest Pathophysiol. 2017 May;8(2):27-38.

18 Singh P, Arora A, Strand TA, Leffler DA, Catassi C, Green PH, et al. Global Prevalence of Celiac Disease: Systematic Review and Metaanalysis. Clin Gastroenterol Hepatol. 2018 Jun;16(6):823-836.e2. 
19 Lionetti E, Gatti S, Pulvirenti A, Catassi C. Celiac disease from a global perspective. Best Pract Res Clin Gastroenterol. 2015;29:365-79.

20 Yuan J, Gao J, Li X, Liu F, Wijmenga C, Chen $\mathrm{H}$, et al. The tip of the "celiac iceberg" in China: a systematic review and meta-analysis. PLoS One. 2013 Dec;8(12):e81151.

21 Poddighe D, Turganbekova A, Baymukasheva $D$, Saduakas $Z$, Zhanzakova $Z$, Abdrakhmanova S. Genetic predisposition to celiac disease in Kazakhstan: potential impact on the clinical practice in Central Asia. PLoS One. 2020 Jan;15(1):e0226546.

22 Poddighe D, Rakhimzhanova M, Marchenko $\mathrm{Y}$, Catassi C. Pediatric celiac disease in central and east asia: current knowledge and prevalence. Medicina (Kaunas). 2019 Jan;55(1):1-8.

23 West J, Fleming KM, Tata LJ, Card TR, Crooks CJ. Incidence and prevalence of celiac disease and dermatitis herpetiformis in the UK over two decades: population-based study. Am J Gastroenterol. 2014 May;109(5): 757-68.

24 Withoff S, Li Y, Jonkers I, Wijmenga C. Understanding Celiac Disease by Genomics. Trends Genet. 2016 May;32(5):295-308

25 McAllister BP, Williams E, Clarke K. A Comprehensive Review of Celiac Disease/GlutenSensitive Enteropathies. Clin Rev Allergy Immunol. 2019 Oct;57(2):226-43.

26 Lebwohl B, Sanders DS, Green PH. Coeliac disease. Lancet. 2018 Jan;391(10115):70-81.

27 Amil Dias J. Celiac Disease: What Do We Know in 2017? GE Port J Gastroenterol. 2017 Nov;24(6):275-8

28 Vriezinga SL, Auricchio R, Bravi E, Castillejo G, Chmielewska A, Crespo Escobar P, et al. Randomized feeding intervention in infants at high risk for celiac disease. $\mathrm{N}$ Engl J Med. 2014 Oct;371(14):1304-15.

29 Aronsson CA, Lee HS, Liu E, Uusitalo U, Hummel S, Yang J, et al.; TEDDY STUDY GROUP. Age at gluten introduction and risk of celiac disease. Pediatrics. 2015 Feb;135(2): $239-45$.

30 Silano M, Agostoni C, Sanz Y, Guandalini S. Infant feeding and risk of developing celiac disease: a systematic review. BMJ Open. 2016 Jan;6(1):e009163.

31 Pinto-Sánchez MI, Verdu EF, Liu E, Bercik P, Green $\mathrm{PH}$, Murray JA, et al. Gluten Introduction to Infant Feeding and Risk of Celiac Disease: Systematic Review and Meta-Analysis. J Pediatr. 2016 Jan;168:132-143.e3.

32 Lionetti E, Castellaneta S, Francavilla R, Pulvirenti A, Tonutti E, Amarri S, et al.; SIGENP (Italian Society of Pediatric Gastroenterology, Hepatology, and Nutrition) Working Group on Weaning and CD Risk. Introduction of gluten, HLA status, and the risk of celiac disease in children. N Engl J Med. 2014 Oct; 371(14):1295-303.

33 Fewtrell M, Bronsky J, Campoy C, Domellöf M, Embleton N, Fidler Mis N, et al. Complementary feeding: A position paper by the $\mathrm{Eu}-$ ropean Society for Paediatric Gastroenterology, Hepatology, and Nutrition (ESPGHAN) committee on nutrition. J Pediatr Gastroenterol Nutr. 2017 Jan;64(1):119-32.

34 Weile B, Cavell B, Nivenius K, Krasilnikoff PA. Striking differences in the incidence of childhood celiac disease between Denmark and Sweden: a plausible explanation. J Pediatr Gastroenterol Nutr. 1995 Jul;21(1):64-8.

35 Szajewska H, Shamir R, Mearin L, RibesKoninckx C, Catassi C, Domellöf M, et al. Gluten introduction and the risk of coeliac disease: A position paper by the european society for pediatric gastroenterology, hepatology, and nutrition. J Pediatr Gastroenterol Nutr. 2016 Mar;62(3):507-13.

36 Szajewska H, Shamir R, Chmielewska A, Pieścik-Lech M, Auricchio R, Ivarsson A, et al.; PREVENTCD Study Group. Systematic review with meta-analysis: early infant feeding and coeliac disease-update 2015. Aliment Pharmacol Ther. 2015 Jun;41(11): 1038-54.

37 Mearin ML. The prevention of coeliac disease. Best Pract Res Clin Gastroenterol. 2015;29: 493-501.

38 Stene LC, Honeyman MC, Hoffenberg EJ, Haas JE, Sokol RJ, Emery L, et al. Rotavirus infection frequency and risk of celiac disease autoimmunity in early childhood: a longitudinal study. Am J Gastroenterol. 2006 Oct; 101(10):2333-40

39 Ludvigsson JF, Murray JA. Epidemiology of Celiac Disease. Gastroenterol Clin North Am. 2019;48:1-18.

40 Nellikkal SS, Hafed Y, Larson JJ, Murray JA, Absah I. High Prevalence of Celiac Disease Among Screened First-Degree Relatives. Mayo Clin Proc. 2019 Sep;94(9):1807-13.

41 Singh P, Arora S, Lal S, Strand TA, Makharia GK. Risk of celiac disease in the first- and second-degree relatives of patients with celiac disease: A systematic review and meta-analysis. Am J Gastroenterol. Am J Gastroenterol. 2015 Nov;110(11):1539-48.

42 Pham-Short A, Donaghue KC, Ambler G, Phelan H, Twigg S, Craig ME. Screening for celiac disease in type 1 diabetes: A systematic review. Pediatrics. 2015 Jul;136(1):e170-6.

43 Elli L, Bonura A, Garavaglia D, Rulli E, Floriani I, Tagliabue G, et al. Immunological comorbity in coeliac disease: associations, risk factors and clinical implications. J Clin Immunol. 2012 Oct;32(5):984-90.

44 Meini A, Pillan NM, Villanacci V, Monafo V, Ugazio AG, Plebani A. Prevalence and diagnosis of celiac disease in IgA-deficient children. Ann Allergy Asthma Immunol. 1996 Oct;77(4):333-6.

45 Carnicer J, Farré C, Varea V, Vilar P, Moreno $\mathrm{J}$, Artigas J. Prevalence of coeliac disease in Down's syndrome. Eur J Gastroenterol Hepatol. 2001 Mar;13(3):263-7.

46 Mårild K, Størdal K, Hagman A, Ludvigsson JF. Turner syndrome and celiac disease: A case-control study. Pediatrics. 2016 Feb; 137(2):e20152232.

47 Guandalini S, Assiri A. Celiac disease: a review. JAMA Pediatr. 2014 Mar;168(3):272-8.
48 Kagnoff MF. Celiac disease: pathogenesis of a model immunogenetic disease. J Clin Invest. 2007 Jan;117(1):41-9.

49 Kagnoff MF. Overview and pathogenesis of celiac disease. Gastroenterology. 2005 Apr; 128(4 Suppl 1):S10-8.

50 Balakireva AV, Zamyatnin AA. Properties of gluten intolerance: gluten structure, evolution, pathogenicity and detoxification capabilities. Nutrients. 2016 Oct;8(10):8.

51 Shan L, Molberg Ø, Parrot I, Hausch F, Filiz F, Gray GM, et al. Structural basis for gluten intolerance in Celiac Sprue. Science. 2002 Sep; 297(5590):2275-9.

52 Stamnaes J, Sollid LM. Celiac disease: autoimmunity in response to food antigen. Semin Immunol. 2015 Sep;27(5):343-52.

53 Leonard MM, Sapone A, Catassi C, Fasano A. Celiac disease and nonceliac gluten sensitivity: A review. JAMA -. JAMA. 2017 Aug; 318(7):647-56.

54 Lammers KM, Lu R, Brownley J, Lu B, Gerard $\mathrm{C}$, Thomas $\mathrm{K}$, et al. Gliadin induces an increase in intestinal permeability and zonulin release by binding to the chemokine receptor CXCR3. Gastroenterology. 2008 Jul;135(1): 194-204.e3.

55 Rescigno M, Di Sabatino A. Dendritic cells in intestinal homeostasis and disease. J Clin Invest. 2009 Sep;119(9):2441-50.

56 Xia J, Sollid LM, Khosla C. Equilibrium and kinetic analysis of the unusual binding behavior of a highly immunogenic gluten peptide to HLADQ2. Biochemistry. 2005 Mar;44(11):4442-9.

57 Sollid LM. The roles of MHC class II genes and post-translational modification in celiac disease. Immunogenetics. 2017 Aug;69(8-9): 605-16.

58 du Pré MF, Sollid LM. T-cell and B-cell immunity in celiac disease. Best Pract Res Clin Gastroenterol. 2015 Jun;29(3):413-23.

59 Poddighe D, Rebuffi C, De Silvestri A, Capittini C. Carrier frequency of HLA-DQB ${ }^{*} 02$ allele in patients affected with celiac disease: A systematic review assessing the potential rationale of a targeted allelic genotyping as a first-line screening. World J Gastroenterol. 2020 Mar;26(12):1365-81.

60 Karinen H, Kärkkäinen P, Pihlajamäki J, Janatuinen E, Heikkinen M, Julkunen R, et al. Gene dose effect of the DQB1*0201 allele contributes to severity of coeliac disease. Scand J Gastroenterol. 2006 Feb;41(2):191-9.

61 Jabri B, Sollid LM. Tissue-mediated control of immunopathology in coeliac disease. Nat Rev Immunol. 2009 Dec;9(12):858-70.

62 Pender SL, Tickle SP, Docherty AJ, Howie D, Wathen NC, MacDonald TT. A major role for matrix metalloproteinases in T cell injury in the gut. J Immunol. $1997 \mathrm{Feb}$;158(4):1582-90.

63 Bajaj-Elliott M, Poulsom R, Pender SL, Wathen NC, MacDonald TT. Interactions between stromal cell-derived keratinocyte growth factor and epithelial transforming growth factor in immune-mediated crypt cell hyperplasia. J Clin Invest. 1998 Oct;102(8): 1473-80. 
64 Sollid LM, Molberg O, McAdam S, Lundin KE. Autoantibodies in coeliac disease: tissue transglutaminase-guilt by association? Gut. 1997 Dec;41(6):851-2.

65 Fernández A, González L, de-la-Fuente J. Coeliac disease: clinical features in adult populations. Rev Esp Enferm Dig. 2010 Jul;102(8): 466-71.

66 Laurikka P, Nurminen S, Kivelä L, Kurppa K. Extraintestinal manifestations of celiac disease: early detection for better long-term outcomes. Nutrients. 2018 Aug;10(8):1-14.

67 Hadjivassiliou M, Sanders DD, Aeschlimann DP. Gluten-related disorders: gluten ataxia. Dig Dis. 2015;33(2):264-8.

68 Bushara KO. Neurologic presentation of celiac disease. Gastroenterology. 2005 Apr; 128(4 Suppl 1):S92-7.

69 Freeman HJ. Neurological disorders in adult celiac disease. Can J Gastroenterol. 2008 Nov; 22(11):909-11.

70 Hadjivassiliou M, Rao DG, Grìnewald RA, Aeschlimann DP, Sarrigiannis PG, Hoggard $\mathrm{N}$, et al. Neurological dysfunction in coeliac disease and non-coeliac gluten sensitivity. Am J Gastroenterol. 2016 Apr;111(4):561-7.

71 Mearns ES, Taylor A, Thomas Craig KJ, Puglielli S, Leffler DA, Sanders DS, et al. Neurological manifestations of neuropathy and ataxia in celiac disease: A systematic review. Nutrients. 2019 Feb;11(2):380.

72 Reunala T, Salmi TT, Hervonen K, Kaukinen K, Collin P. Dermatitis herpetiformis: A common extraintestinal manifestation of coeliac disease. Nutrients. 2018 May;10(5):1-9.

73 Husby S, Koletzko S, Korponay-Szabó IR, Mearin ML, Phillips A, Shamir R, et al.; ESPGHAN Working Group on Coeliac Disease Diagnosis; ESPGHAN Gastroenterology Committee; European Society for Pediatric Gastroenterology, Hepatology, and Nutrition. European Society for Pediatric Gastroenterology, Hepatology, and Nutrition guidelines for the diagnosis of coeliac disease. J Pediatr Gastroenterol Nutr. 2012 Jan;54(1):136-60.

74 Pellegrini FP, Marinoni M, Frangione V, Tedeschi A, Gandini V, Ciglia F, et al. Down syndrome, autoimmunity and T regulatory cells. Clin Exp Immunol. 2012 Sep;169(3):238-43.

75 Kahaly GJ, Frommer L, Schuppan D. Celiac disease and endocrine autoimmunity - the genetic link. Autoimmun Rev. 2018 Dec;17(12): 1169-75.

76 Ventura A, Magazzù G, Greco L; SIGEP Study Group for Autoimmune Disorders in Celiac Disease. Duration of exposure to gluten and risk for autoimmune disorders in patients with celiac disease. Gastroenterology. 1999 Aug;117(2):297-303.

77 Rodrigues F, Bachmeyer C. Coeliac disease and dermatitis herpetiformis. Lancet. 2018 Sep;392(10151):916.

78 Sørensen HT, Thulstrup AM, Blomqvist P, Nørgaard B, Fonager K, Ekbom A. Risk of primary biliary liver cirrhosis in patients with coeliac disease: danish and Swedish cohort data. Gut. 1999 May;44(5):736-8.
79 Ludvigsson JF, Elfström P, Broomé U, Ekbom A, Montgomery SM. Celiac disease and risk of liver disease: a general population-based study. Clin Gastroenterol Hepatol. 2007 Jan; 5(1):63-69.e1.

80 Korponay-Szabó IR, Dahlbom I, Laurila K, Koskinen S, Woolley N, Partanen J, et al. Elevation of IgG antibodies against tissue transglutaminase as a diagnostic tool for coeliac disease in selective IgA deficiency. Gut. 2003 Nov;52(11):1567-71.

81 Kumar V, Jarzabek-Chorzelska M, Sulej J, Karnewska K, Farrell T, Jablonska S. Celiac disease and immunoglobulin a deficiency: how effective are the serological methods of diagnosis? Clin Diagn Lab Immunol. 2002 Nov;9(6):1295-300.

82 Rubio-Tapia A, Hill ID, Kelly CP, Calderwood AH, Murray JA; American College of Gastroenterology. ACG clinical guidelines: diagnosis and management of celiac disease. Am J Gastroenterol. 2013 May; 108(5):656-76.

83 Al-Toma A, Volta U, Auricchio R, Castillejo G, Sanders DS, Cellier C, et al. European Society for the Study of Coeliac Disease (ESsCD) guideline for coeliac disease and other glutenrelated disorders. United European Gastroenterol J. 2019 Jun;7(5):583-613.

84 Husby S, Koletzko S, Korponay-Szabó I, Kurppa K, Mearin ML, Ribes-Koninckx C, et al. European Society Paediatric Gastroenterology, Hepatology and Nutrition Guidelines for Diagnosing Coeliac Disease 2020. J Pediatr Gastroenterol Nutr. 2020 Jan;70(1):14156.

85 Irvine AJ, Chey WD, Ford AC. Screening for Celiac Disease in Irritable Bowel Syndrome: An Updated Systematic Review and Metaanalysis. Am J Gastroenterol. 2017 Jan;112(1): 65-76.

86 Downey L, Houten R, Murch S, Longson D.; Guideline Development Group. Recognition, assessment, and management of coeliac disease: summary of updated NICE guidance. BMJ. 2015 Sep;351:h4513.

87 Ludvigsson JF, Card TR, Kaukinen K, Bai J, Zingone F, Sanders DS, et al. Screening for celiac disease in the general population and in high-risk groups. United European Gastroenterol J. 2015 Apr;3(2):106-20.

88 Leffler DA, Kelly CP. The cost of a loaf of bread in symptomless celiac disease. Gastroenterology. 2014 Sep;147(3):557-9.

89 Elli L, Ferretti F, Orlando S, Vecchi M, Monguzzi E, Roncoroni L, et al. Management of celiac disease in daily clinical practice. Eur J Intern Med. 2018;61:15-24.

90 Kowalski K, Mulak A, Jasińska M, Paradowski L. Diagnostic challenges in celiac disease. Adv Clin Exp Med. 2017 Jul;26(4):729-37.

91 Schyum AC, Rumessen JJ. Serological testing for celiac disease in adults. United European Gastroenterol J. 2013 Oct;1(5):319-25.

92 Korponay-Szabó IR, Troncone R, Discepolo $\mathrm{V}$. Adaptive diagnosis of coeliac disease. Best Pract Res Clin Gastroenterol. 2015 Jun;29(3): 381-98.
93 Lau MS, Sanders DS. Optimizing the diagnosis of celiac disease. Curr Opin Gastroenterol. 2017 May;33(3):173-80.

94 Hanevik K, Wik E, Langeland N, Hausken T. Transient elevation of anti-transglutaminase and anti-endomysium antibodies in Giardia infection. Scand J Gastroenterol. 2018;53(7):809-12.

95 Vecchi M, Folli C, Donato MF, Formenti S, Arosio E, de Franchis R. High rate of positive anti-tissue transglutaminase antibodies in chronic liver disease. Role of liver decompensation and of the antigen source. Scand J Gastroenterol. 2003 Jan;38(1):50-4.

96 Peracchi M, Trovato C, Longhi M, Gasparin $\mathrm{M}$, Conte D, Tarantino C, et al. Tissue transglutaminase antibodies in patients with endstage heart failure. Am J Gastroenterol. 2002 Nov;97(11):2850-4.

97 Castillo NE, Theethira TG, Leffler DA. The present and the future in the diagnosis and management of celiac disease. Gastroenterol Rep (Oxf). 2015 Feb;3(1):3-11.

98 Emami MH, Karimi S, Nemati A. Do endoscopic markers still play a role in the diagnosis of celiac disease? Indian J Gastroenterol. 2008 Sep-Oct;27(5):183-5.

99 Dickey W. Endoscopic markers for celiac disease. Nat Clin Pract Gastroenterol Hepatol. 2006 Oct;3(10):546-51.

100 Ianiro G, Gasbarrini A, Cammarota G. Endoscopic tools for the diagnosis and evaluation of celiac disease. World J Gastroenterol. 2013 Dec;19(46):8562-70.

101 Balaban DV, Popp A, Vasilescu F, Haidautu D, Purcarea RM, Jinga M. Diagnostic yield of endoscopic markers for celiac disease. J Med Life. 2015 Oct-Dec;8(4):452-7.

102 Cammarota G, Pirozzi GA, Martino A, Zuccalà G, Cianci R, Cuoco L, et al. Reliability of the "immersion technique" during routine upper endoscopy for detection of abnormalities of duodenal villi in patients with dyspepsia. Gastrointest Endosc. 2004 Aug;60(2):223-8.

103 Dutta AK, Sajith KG, Shah G, Pulimood AB, Simon EG, Joseph AJ, et al. Duodenal villous morphology assessed using magnification narrow band imaging correlates well with histology in patients with suspected malabsorption syndrome. Dig Endosc. 2014 Nov; 26(6):720-5.

104 Cammarota G, Ianiro G, Sparano L, La Mura R, Ricci R, Larocca LM, et al. Image-enhanced endoscopy with I-scan technology for the evaluation of duodenal villous patterns. Dig Dis Sci. 2013 May;58(5):1287-92.

105 Leong RW, Nguyen NQ, Meredith CG, AlSohaily S, Kukic D, Delaney PM, et al. In vivo confocal endomicroscopy in the diagnosis and evaluation of celiac disease. Gastroenterology. 2008 Dec;135(6):1870-6.

106 Penny HA, Mooney PD, Burden M, Patel N, Johnston AJ, Wong SH, et al. High definition endoscopy with or without I-Scan increases the detection of celiac disease during routine endoscopy. Dig Liver Dis. 2016 Jun; 48(6):644-9. 
107 Lewis SK, Semrad CE. Capsule Endoscopy and Enteroscopy in Celiac Disease. Gastroenterol Clin North Am. 2019;48:73-84.

108 McCarty TR, O’Brien CR, Gremida A, Ling C, Rustagi T. Efficacy of duodenal bulb biopsy for diagnosis of celiac disease: a systematic review and meta-analysis. Endosc Int Open. 2018 Nov;6(11):E1369-78.

109 Taavela J, Popp A, Korponay-Szabo IR, Ene A, Vornanen M, Saavalainen P, et al. A Prospective Study on the Usefulness of Duodenal Bulb Biopsies in Celiac Disease Diagnosis in Children: urging Caution. Am J Gastroenterol. 2016 Jan;111(1):12433.

110 Voutilainen M, Juhola M, Färkkilä M, Sipponen P. Gastric metaplasia and chronic inflammation at the duodenal bulb mucosa. Dig Liver Dis. 2003 Feb;35(2):94-8.

111 Padda S, Shah I, Ramirez FC. Adequacy of mucosal sampling with the "two-bite" forceps technique: a prospective, randomized, blinded study. Gastrointest Endosc. 2003 Feb;57(2):170-3.

112 Latorre M, Lagana SM, Freedberg DE, Lewis SK, Lebwohl B, Bhagat G, et al. Endoscopic biopsy technique in the diagnosis of celiac disease: one bite or two? Gastrointest Endosc. 2015 May;81(5):1228-33.

113 Oberhuber G. Histopathology of celiac disease. Biomed Pharmacother. 2000 Aug; 54(7):368-72.

114 Brown I, Mino-Kenudson M, Deshpande V, Lauwers GY. Intraepithelial lymphocytosis in architecturally preserved proximal small intestinal mucosa: an increasing diagnostic problem with a wide differential diagnosis. Arch Pathol Lab Med. 2006 Jul;130(7):10205.

115 Ciccocioppo R, Kruzliak P, Cangemi GC, Pohanka M, Betti E, Lauret E, et al. The spectrum of differences between childhood and adulthood celiac disease. Nutrients. 2015 Oct;7(10):8733-51.

116 Ludvigsson JF, Bai JC, Biagi F, Card TR, Ciacci C, Ciclitira PJ, et al.; BSG Coeliac Disease Guidelines Development Group; British Society of Gastroenterology. Diagnosis and management of adult coeliac disease: guidelines from the British Society of Gastroenterology. Gut. 2014 Aug;63(8):121028

117 Sollid LM, Lie BA. Celiac disease genetics: current concepts and practical applications. Clin Gastroenterol Hepatol. 2005 Sep;3(9): 843-51.

118 Sciurti M, Fornaroli F, Gaiani F, Bonaguri C, Leandro G, Di Mario F, et al. Genetic susceptibilty and celiac disease: what role do HLA haplotypes play? Acta Biomed. 2018 Dec;89 9-S:17-21.

119 Fuchs V, Kurppa K, Huhtala H, Laurila K, Mäki M, Collin P, et al. Serology-based criteria for adult coeliac disease have excellent accuracy across the range of pre-test probabilities. Aliment Pharmacol Ther. 2019 Feb; 49(3):277-84.
120 Adriaanse MP, Tack GJ, Passos VL, Damoiseaux JG, Schreurs MW, van Wijck K, et al. Serum I-FABP as marker for enterocyte damage in coeliac disease and its relation to villous atrophy and circulating autoantibodies. Aliment Pharmacol Ther. 2013 Feb; 37(4):482-90.

121 Adriaanse MP, Leffler DA, Kelly CP, Schuppan D, Najarian RM, Goldsmith JD, et al. Serum I-FABP Detects Gluten Responsiveness in Adult Celiac Disease Patients on a ShortTerm Gluten Challenge. Am J Gastroenterol. 2016 Jul;111(7):1014-22.

122 Sarna VK, Lundin KE, Mørkrid L, Qiao SW, Sollid LM, Christophersen A. HLA-DQGluten Tetramer Blood Test Accurately Identifies Patients With and Without Celiac Disease in Absence of Gluten Consumption. Gastroenterology. 2018 Mar;154(4):886896.e6.

123 Sarna VK, Skodje GI, Reims HM, Risnes LF, Dahal-Koirala S, Sollid LM, et al. HLADQ:gluten tetramer test in blood gives better detection of coeliac patients than biopsy after 14-day gluten challenge. Gut. 2018 Sep; 67(9):1606-13.

124 Schiepatti A, Biagi F, Fraternale G, Vattiato C, Balduzzi D, Agazzi S, et al. Short article: mortality and differential diagnoses of villous atrophy without coeliac antibodies. Eur J Gastroenterol Hepatol. 2017 May;29(5): $572-6$.

125 Volta U, Caio G, Boschetti E, Giancola F, Rhoden KJ, Ruggeri E, et al. Seronegative celiac disease: shedding light on an obscure clinical entity. Dig Liver Dis. 2016 Sep;48(9): 1018-22.

126 Aziz I, Peerally MF, Barnes JH, Kandasamy V, Whiteley JC, Partridge D, et al. The clinical and phenotypical assessment of seronegative villous atrophy; a prospective UK centre experience evaluating 200 adult cases over a 15-year period (2000-2015). Gut. 2017 Sep;66(9):1563-72.

127 Schiepatti A, Sanders DS, Biagi F. Seronegative coeliac disease: clearing the diagnostic dilemma. Curr Opin Gastroenterol. 2018 May;34(3):154-8.

128 Elli L, Branchi F, Sidhu R, Guandalini S, Assiri A, Rinawi F, et al. Small bowel villous atrophy: celiac disease and beyond. Expert Rev Gastroenterol Hepatol. 2017 Feb;11(2): $125-38$.

129 Jansson-Knodell CL, Hujoel IA, RubioTapia A, Murray JA. Not All That Flattens Villi Is Celiac Disease: A Review of Enteropathies. Mayo Clin Proc. 2018 Apr;93(4): 509-17.

130 Kamboj AK, Oxentenko AS. Clinical and Histologic Mimickers of Celiac Disease. Clin Transl Gastroenterol. 2017 Aug;8(8):e114.

131 Walker MM, Murray JA, Ronkainen J, Aro P, Storskrubb T, D'Amato M, et al. Detection of celiac disease and lymphocytic enteropathy by parallel serology and histopathology in a population-based study. Gastroenterology. 2010 Jul;139(1):112-9.
132 Salmi TT, Collin P, Korponay-Szabó IR, Laurila K, Partanen J, Huhtala H, et al. Endomysial antibody-negative coeliac disease: clinical characteristics and intestinal autoantibody deposits. Gut. 2006 Dec;55(12):1746-53.

133 Ierardi E, Losurdo G, Piscitelli D, Giorgio F, Sorrentino C, Principi M, et al. Seronegative celiac disease: where is the specific setting? Gastroenterol Hepatol Bed Bench. 2015; $8(2): 110-6$.

134 Tosco A, Salvati VM, Auricchio R, Maglio M, Borrelli M, Coruzzo A, et al. Natural History of Potential Celiac Disease in Children. Clin Gastroenterol Hepatol. 2011;9:320-5.

135 Auricchio R, Tosco A, Piccolo E, Galatola M, Izzo V, Maglio M, et al. Potential celiac children: 9-year follow-up on a gluten-containing diet. Am J Gastroenterol. 2014 Jun; 109(6):913-21.

136 Volta U, Caio G, Giancola F, Rhoden KJ, Ruggeri E, Boschetti E, et al. Features and Progression of Potential Celiac Disease in Adults. Clin Gastroenterol Hepatol. 2016; 14:686-693.e1.

137 Lionetti E, Castellaneta S, Francavilla R, Pulvirenti A, Naspi Catassi G, Catassi C; SIGENP Working Group of Weaning and CD Risk. Long-Term Outcome of Potential Celiac Disease in Genetically at-Risk Children: The Prospective CELIPREV Cohort Study. J Clin Med. 2019 Feb;8(2):186

138 Leffler D, Schuppan D, Pallav K, Najarian R, Goldsmith JD, Hansen J, et al. Kinetics of the histological, serological and symptomatic responses to gluten challenge in adults with coeliac disease. Gut. 2013 Jul;62(7):996-1004.

139 Sapone A, Bai JC, Ciacci C, Dolinsek J, Green PH, Hadjivassiliou M, et al. Spectrum of gluten-related disorders: consensus on new nomenclature and classification. BMC Med. 2012 Feb;10(1):13.

140 Volta U, De Giorgio R, Caio G, Uhde M, Manfredini R, Alaedini A. Nonceliac Wheat Sensitivity: An Immune-Mediated Condition with Systemic Manifestations. Gastroenterol Clin North Am. 2019 Mar;48(1): $165-82$.

141 Catassi C, Elli L, Bonaz B, Bouma G, Carroccio A, Castillejo G, et al. Diagnosis of nonceliac gluten sensitivity (NCGS): the salerno experts' criteria. Nutrients. 2015 Jun;7(6): 4966-77.

142 Schuppan D, Pickert G, Ashfaq-Khan M, Zevallos V. Non-celiac wheat sensitivity: differential diagnosis, triggers and implications. Best Pract Res Clin Gastroenterol. 2015 Jun;29(3):469-76.

143 Volta U, Caio G, De Giorgio R, Henriksen C Skodje G, Lundin KE. Non-celiac gluten sensitivity: A work-in-progress entity in the spectrum of wheat-related disorders. Best Pract Res Clin Gastroenterol. 2015;29:47791.

144 Mansueto P, Seidita A, D’Alcamo A, Carroccio A. Non-celiac gluten sensitivity: literature review. J Am Coll Nutr. 2014;33(1):3954 
145 Bascuñán KA, Vespa MC, Araya M. Celiac disease: understanding the gluten-free diet. Eur J Nutr. 2017 Mar;56(2):449-59.

146 Dennis M, Lee AR, McCarthy T. Nutritional Considerations of the Gluten-Free Diet. Gastroenterol Clin North Am. 2019;48:53-72.

147 Akobeng AK, Thomas AG. Systematic review: tolerable amount of gluten for people with coeliac disease. Aliment Pharmacol Ther. 2008 Jun;27(11):1044-52.

148 Hischenhuber C, Crevel R, Jarry B, Mäki M, Moneret-Vautrin DA, Romano A, et al. Review article: safe amounts of gluten for patients with wheat allergy or coeliac disease. Aliment Pharmacol Ther. 2006 Mar;23(5):559-75.

149 Oxentenko AS, Murray JA. Celiac Disease: Ten Things That Every Gastroenterologist Should Know. Clin Gastroenterol Hepatol. Elsevier, Inc; 2015. p. 13.

150 Rashid M, Lee J. Serologic testing in celiac disease: practical guide for clinicians. Can Fam Physician. 2016 Jan;62(1):38-43.

151 Zanini B, Lanzarotto F, Mora A, Bertolazzi S, Turini D, Cesana B, et al. Five year time course of celiac disease serology during gluten free diet: results of a community based "CD-Watch" program. Dig Liver Dis. 2010 Dec;42(12):865-70.

152 Mulder CJ, Wierdsma NJ, Berkenpas M, Jacobs MAJM, Bouma G. Preventing complications in celiac disease: Our experience with managing adult celiac disease. Best Pract Res Clin Gastroenterol. 2015;29:459-68.

153 Galli G, Esposito G, Lahner E, Pilozzi E, Corleto VD, Di Giulio E, et al. Histological recovery and gluten-free diet adherence: a prospective 1-year follow-up study of adult patients with coeliac disease. Aliment Pharmacol Ther. 2014 Sep;40(6):639-47.
154 Malamut G, Cellier C. Complications of coeliac disease. Best Pract Res Clin Gastroenterol. 2015;29:451-8.

155 Matysiak-Budnik T, Malamut G, de Serre NP, Grosdidier E, Seguier S, Brousse N, et al. Long-term follow-up of 61 coeliac patients diagnosed in childhood: evolution toward latency is possible on a normal diet. Gut. 2007 Oct;56(10):1379-86.

156 Hall NJ, Rubin G, Charnock A. Systematic review: adherence to a gluten-free diet in adult patients with coeliac disease. Aliment Pharmacol Ther. 2009 Aug;30(4):315-30.

157 Leffler DA, Edwards-George J, Dennis M, Schuppan D, Cook F, Franko DL, et al. Factors that influence adherence to a gluten-free diet in adults with celiac disease. Dig Dis Sci. 2008 Jun;53(6):1573-81.

158 Corrao G, Corazza GR, Bagnardi V, Brusco G, Ciacci C, Cottone M, et al. Mortality in patients with coeliac disease and their relatives: a cohort study. Lancet. 2001;358:35661.

159 Costes LM, Meresse B, Cerf-Bensussan N, Samsom JN. The role of animal models in unravelling therapeutic targets in coeliac disease. Best Pract Res Clin Gastroenterol. 2015 Jun;29(3):437-50.

160 Malamut G, Cellier C. Refractory celiac disease: epidemiology and clinical manifestations. Dig Dis. 2015;33(2):221-6.

161 Roshan B, Leffler DA, Jamma S, Dennis M, Sheth S, Falchuk K, et al. The incidence and clinical spectrum of refractory celiac disease in a north american referral center. Am J Gastroenterol. 2011 May;106(5):923-8.
162 Nijeboer P, van Wanrooij R, van Gils T, Wierdsma NJ, Tack GJ, Witte BI, et al. Lymphoma development and survival in refractory coeliac disease type II: histological response as prognostic factor. United European Gastroenterol J. 2017 Mar;5(2): 208-17.

163 Malamut G, Cellier C. Refractory Celiac Disease. Gastroenterol Clin North Am. 2019;48: $137-44$.

164 Catassi C, Bearzi I, Holmes GK. Association of celiac disease and intestinal lymphomas and other cancers. Gastroenterology. 2005 Apr;128(4 Suppl 1):S79-86.

165 Ilus T, Kaukinen K, Virta LJ, Pukkala E, Collin P. Incidence of malignancies in diagnosed celiac patients: a population-based estimate. Am J Gastroenterol. 2014 Sep;109(9): 1471-7.

166 Tio M, Cox MR, Eslick GD. Meta-analysis: coeliac disease and the risk of all-cause mortality, any malignancy and lymphoid malignancy. Aliment Pharmacol Ther. 2012 Mar 35(5):540-51.

167 Lebwohl B, Green PH, Söderling J, Roelstraete B, Ludvigsson JF. Association Between Celiac Disease and Mortality Risk in a Swedish Population. JAMA. 2020 Apr; 323(13):1277-85.

168 Biagi F, Corazza GR. Do different patients with coeliac disease have different mortality rates? Gut. 2015 Aug;64(8):1187-8.

169 Koskinen I, Virta LJ, Huhtala H, Ilus T, Kaukinen K, Collin P. Overall and CauseSpecific Mortality in Adult Celiac Disease and Dermatitis Herpetiformis Diagnosed in the 21st Century. Am J Gastroenterol. 2020 Jul;115(7):1117-24. 